\title{
The Relationship between Social Support and \\ Demographic Characteristics among Malaysian University Students during the Covid-19 Pandemic
}

\begin{abstract}
Mohd Rizal Hussain
Malaysian Research Institute on Ageing, Universiti Putra Malaysia, 43400 UPM Serdang, Selangor
\end{abstract}

Nor Syazila Abdul Rahim

Faculty of Educational Studies, Universiti Putra Malaysia, 43400 UPM Serdang, Selangor

Fatma Azwani Abdul Aziz

Institute of Tropical Agriculture and Food Security (ITAFoS), Universiti Putra Malaysia, 43400 UPM Serdang, Selangor

Rahmawati Umar

School of Graduate Studies, Universiti Putra Malaysia, 43400 UPM Serdang, Selangor

Yap Wing Fen

Faculty of Science, Universiti Putra Malaysia, 43400 UPM Serdang, Selangor

Aminuddin Hassan (Corresponding authors)

Faculty of Educational Studies, Universiti Putra Malaysia, 43400 UPM Serdang, Selangor

Norshahilda Md Shahril

Tun Dr. Ismail College, Universiti Putra Malaysia, 43400 UPM Serdang, Selangor 
Muhammad Fathul Ariffin Mohd Fauzi

Tun Dr Ismail College, Universiti Putra Malaysia, 43400 UPM Serdang, Selangor

Amini Amir Abdullah

Faculty of Human Ecology, Universiti Putra Malaysia, 43400 UPM Serdang, Selangor

Received: Oct. 8, $2021 \quad$ Accepted: Nov. 15, 2021 Online published: Nov. 22, 2021

doi:10.5296/ijhrs.v11i4S.19232 URL: https://doi.org/10.5296/ijhrs.v11i4S.19232

\begin{abstract}
The COVID-19 pandemic is one of the fastest and most widespread epidemics affecting the world today, and its impacts are also experienced in Malaysia. The pandemic has a huge impact on the social, economic, and educational livelihood of the community. Furthermore, the government's implementation of the Movement Control Order (MCO) has resulted in most sectors not operating at full capacity, including higher education institutions. This situation has largely affected the field of education. Thus, this study was conducted to explore the relationship between social support and demographic characteristics among the Universiti Putra Malaysia (UPM) students during the COVID-19 pandemic. The study adopted the quantitative survey research design and involved 468 randomly sampled participants. Data were collected using a digital questionnaire developed using Google Form and distributed through social media applications. The Statistical Package for the Social Science (SPSS) software was used to analyze the data obtained. The study's findings showed that there was no significant difference between social support and sociodemographic backgrounds. Apart from that, the study also found a significant correlation between the three elements of social support (family, peer, and other close individual). Therefore, continuous social support must be fully utilized in order to avoid the emergence of any issues that can have a negative impact on students, thereby affecting their academic achievement and progress.
\end{abstract}

Keywords: COVID-19 pandemic, university students, social support, demographic characteristics, Malaysia

\title{
1. Introduction
}

At the end of 2019, the world was shocked by the discovery of the novel coronavirus (SARS-CoV-2), later known as COVID-19, which causes the severe acute respiratory syndrome. Soon after, the virus has declared a pandemic due to its spread worldwide (Harapan et al., 2020). To date, scientists worldwide are still working to find vaccines and treatments that are truly effective in fighting the virus. Although vaccines have been administered as a preventive measure to control the pandemic, social distancing and isolation are still practiced everywhere as infection rates are still high. Malaysia is also affected by the 
spread of this disease. This situation has had a huge impact on the life of society, not only on the social and economic aspects but also the educational aspect. According to the OECD (2020), the impact of the COVID-19 pandemic is heterogeneous as it affects people's aspects such as health, economic, social, and fiscal.

The government's implementation of the Movement Control Order (MCO) has forced almost all sectors and activities, including higher education institutions, to operate at half or fraction of their full capacity. Furthermore, due to the prolonged pandemic situation and burdensome measures such as movement control and lockdowns, the COVID-19 pandemic also has a negative impact on higher education (Son et al., 2020). The COVID-19 pandemic has had a major impact on students' psychology and social support (El-Zoghby et al., 2020). According to previous studies, people who are exposed to the persistent risk and uncertainty of infectious diseases have a higher rate of psychological or mental health issues (T.B. Liu, X.Y. Chen, G.D. Miao, et al., 2003). Social support is defined as the support and contribution given or potentially by individuals, groups, communities, and systems related to the individual concerned (Şahin et al., 2019). According to Alia Ashrani et al. (2016), social support is an experience related to love, attention, and appreciation gained from family members, friends, neighbours, or other people who can contribute to positive individual development. Therefore, the implementation of the Movement Control Order (MCO) to control the COVID-19 pandemic has indirectly limited interactions between students, their family, and friends. Being away from their family, students in university residential colleges often get moral and emotional support from friends, fellows, and even lecturers. However, during this pandemic, their interaction with others has become limited. As a result, students face constraints to do social activities such as meeting friends, going out for leisure or being involved in co-curricular activities as before. This situation has severely affected students' emotions and mental health. According to Sundarasen et al. (2020), students living alone experience the highest anxiety level compared to those living with family and friends. As a result of their loneliness, they are at risk of harming their health and safety. The lack of social support determines mental health problems (Alsubaie, Stain, Webster, \& Wadman, 2019). It has been associated with various indicators of psychological stress such as depression and loneliness (Eskin, 2003). The limited physical and functional activity as well as family support could also have a negative impact on students' psychological well-being ( $\mathrm{Li}$ et al., 2021). Thus, social support is an important factor influencing students' mental health as they experience unforeseen emergencies like the COVID-19 pandemic (Guo et al., 2021).

Therefore, this study has been conducted to explore the relationship between social support and demographic characteristics among Universiti Putra Malaysia (UPM) students during the COVID-19 pandemic.

\section{Method}

\subsection{Research Design, Population and Data Collection}

This study has adopted a quantitative design. Simple random sampling was conducted to select 468 UPM students who are residents of ten residential colleges located in UPM Serdang and Bintulu Campuses. These students came from various backgrounds and were 
still studying when this survey was conducted in early August 2021. The questionnaire was developed using Google Form and was distributed through the WhatsApp social media application. According to Dewaele (2018), using online/digital questionnaires is more cost-efficient than conventional methods. Moreover, it allows researchers to collect data from respondents from a wider background in less time. This has indirectly strengthened the validity of the data.

\subsection{Research Instrument}

Respondents' Demographic Background

Respondents' background information includes their age, gender, race, level of education, year of study, residential college, estimated monthly family income, and location where they attend online teaching and learning during the COVID-19 pandemic.

\section{Social Support}

Sources of social support were measured using the Malay version of the Multidimensional Scale of Perceived Social Support (MSPSS) instrument, which was translated by $\mathrm{Ng}$ et al. (2010) from the original instrument developed by Zimet et al. (1988). The instrument contains 12 questions, and it is divided into three parts which represent different forms of support, namely family support (questions 3,4,8,11), peer support (questions 6,7,9,12), and support from other individuals (questions 1,2,5,10). Among the questions used in this instrument are 'I have a special friend to share love and grief with', 'I get the necessary emotional help and support from my family', and 'I can talk about my problems with friends. This instrument uses a 7-point Likert scale ranging from $1=$ strongly disagree to $7=$ strongly agree. The overall score range is between $12-84$, where a score of 12-48 indicates low social support, 49-68 moderate social support, and 69-84 high social support.

Furthermore, the score range for each form of support is 4-28. The results of previous studies showed that MSPSS has been psychometrically proven in various samples and have strong Cronbach's Alpha reliability values and validity (Guan et al., 2013). The Cronbach's Alpha reliability value for the pilot test conducted on 55 students is 0.933 . The Cronbach's Alpha reliability value for each form of social support is 0.957 for other people, 0.929 (family), and 0.927 (friend).

\subsection{Data Analysis}

The data were analyzed using Statistical Program for Social Sciences (SPSS) version 22. The statistical analysis comprises instrument reliability (Cronbach's Alpha), descriptive statistics, T-test, One-Way Analysis of Variance (ANOVA), and Pearson Correlation analysis.

\subsection{Ethical Considerations}

There are no ethical issues in this study. This study did not involve physical contact with the respondents, except through the online survey questionnaire form. In addition, there are no tests involving clinical aspects and the use of drugs because this study is more of a social science nature. The respondents' involvement is also voluntary. The questionnaire has stated 
that the respondents' responses indicate their consent to become the study's respondents. Respondents' data such as full name, matrix number, and telephone number were not shared and mentioned in the study findings in adherence to the Personal Data Protection Act 2010.

\section{Results and Discussion}

\subsection{Respondents' Demographic Background}

The results in Table 1 show that the majority of respondents are female (77.1\%), Malay (70.1\%), studying for their Bachelor's degree (92.9\%), residents of Kolej Tun Dr. Ismail, UPM (40.2\%), and studying in their first year (44.7\%). Meanwhile, the respondents' mean age is 21.24 years (standard deviation $=1.359$ ), and their mean estimated family monthly income is RM4,145.59 (standard deviation $=4061.947$ ).

Table 1. Descriptive Analysis of Respondents' Backgrounds

\begin{tabular}{|c|c|c|c|c|}
\hline Item & $\mathbf{n}$ & $\%$ & Mean & $\begin{array}{l}\text { Standard } \\
\text { Deviation }\end{array}$ \\
\hline Age & 468 & 100 & 21.24 & 1.359 \\
\hline \multicolumn{5}{|l|}{$\operatorname{Sex}$} \\
\hline Male & 107 & 22.9 & & \\
\hline Female & 361 & 77.1 & & \\
\hline \multicolumn{5}{|l|}{ Race } \\
\hline Malay & 328 & 70.1 & & \\
\hline Chinese & 74 & 15.8 & & \\
\hline Indian & 24 & 5.1 & & \\
\hline Bumiputera Sabah/Sarawak & 37 & 7.9 & & \\
\hline Others & 5 & 1.1 & & \\
\hline \multicolumn{5}{|l|}{ Residential College } \\
\hline Kolej Tun Dr. Ismail & 188 & 40.2 & & \\
\hline Kolej Canselor & 3 & 0.6 & & \\
\hline Kolej Sultan Alaeddin & 8 & 1.7 & & \\
\hline \multicolumn{5}{|l|}{ Suleiman Shah } \\
\hline Kolej Pendeta Za'ba & 88 & 18.8 & & \\
\hline Kolej Sepuluh & 55 & 11.8 & & \\
\hline Kolej Dua Belas & 24 & 5.1 & & \\
\hline Kolej Empat Belas & 37 & 7.9 & & \\
\hline Kolej Tujuh Belas & 1 & 0.2 & & \\
\hline Kolej Sri Rajang & 64 & 13.7 & & \\
\hline \multicolumn{5}{|l|}{ Level of study } \\
\hline Diploma & 31 & 6.6 & & \\
\hline Bachelor & 435 & 92.9 & & \\
\hline Master & 1 & 0.2 & & \\
\hline $\mathrm{PhD}$ & 1 & 0.2 & & \\
\hline
\end{tabular}


Year of Study

Year 1

Year 2

Year 3

Year 4

Year 5

Year 5 and more

Estimated family household monthly income (Per month) (RM)

Location when attending online $\mathrm{T} \& \mathrm{~L}$

Home

69.0

Residential College

101

43

Residential College and

Faculty/Institute
209

184

44.7

64

8

2

1

460

98.3

RM4,145.5

9

4061.947

External Organization/Agency $\quad 1 \quad 2.0$

3.2 The Relationship between Respondents' Sociodemographic Background and Social Support

The analysis was conducted to determine the relationship between the demographic background of the respondents with the level of social support from family, friends, and other people) the respondents received during the COVID-19 pandemic and the implementation of the Movement Control Order (MCO). The results of the T-test and ANOVA analysis shown in Tables 2, 3 and 4 below indicate no significant differences between social support received from family, friends and other people close to them across students with different ages, gender, race, level of study, year of study, estimated family monthly income and location where they attend T\&L online . Previous studies have reported varied findings (Gray et al., 2020; Guo et al., 2021; Paykani et al., 2020). The mean scores are relatively high for all three sources of support, with family support (20.03-21.34), peer support (20.06-21.84), and other people (17.00-20.30). Thus, it is possible that during the COVID-19 pandemic situation and the implementation of the $\mathrm{MCO}$, the respondents received more social support from various parties as they want to ensure that the students can emotionally cope with the challenging situation. 
Table 2. The Relationship Between Respondents' Background and Family Support

\begin{tabular}{|c|c|c|c|c|c|c|c|}
\hline Item & & $\mathbf{n}$ & $\%$ & Mean & $\begin{array}{l}\text { Standard } \\
\text { Deviation }\end{array}$ & $\mathbf{t} / \mathbf{F}$ & P value \\
\hline \multirow[t]{3}{*}{ Age } & 20 and below & 121 & 25.9 & 20.97 & 5.679 & 1.250 & 0.287 \\
\hline & $21-22$ & 292 & 62.3 & 21.74 & 5.496 & & \\
\hline & 23 and above & 55 & 11.8 & 22.22 & 5.050 & & \\
\hline \multirow[t]{2}{*}{ Sex } & Male & 107 & 22.9 & 21.50 & 5.438 & 0.220 & 0.826 \\
\hline & Female & 361 & 77.1 & 21.63 & 5.522 & & \\
\hline \multirow[t]{4}{*}{ Race } & Malay & 328 & 70.1 & 21.23 & 5.650 & 1.973 & 0.117 \\
\hline & Chinese & 74 & 15.8 & 22.31 & 4.388 & & \\
\hline & Indian and others & 29 & 6.2 & 23.34 & 5.143 & & \\
\hline & $\begin{array}{l}\text { Bumiputera } \\
\text { Sabah/ Sarawak }\end{array}$ & 37 & 7.9 & 22.05 & 6.123 & & \\
\hline \multirow{3}{*}{$\begin{array}{l}\text { Level } \\
\text { Study }\end{array}$} & \multirow{3}{*}{$\begin{array}{l}\text { Diploma } \\
\text { others } \\
\text { Bachelor }\end{array}$} & 33 & 7.1 & 20.03 & 6.706 & 1.703 & 0.089 \\
\hline & & 435 & 92.9 & 21.72 & 5.385 & & \\
\hline & & & & & & & \\
\hline \multirow{3}{*}{$\begin{array}{l}\text { Year } \\
\text { Study }\end{array}$} & Year 1 & 209 & 44.7 & 21.72 & 5.338 & 0.097 & 0.908 \\
\hline & Year 2 & 184 & 39.3 & 21.49 & 5.398 & & \\
\hline & Year 3 and above & 75 & 16.0 & 21.52 & 6.202 & & \\
\hline \multirow{4}{*}{$\begin{array}{l}\text { Estimated } \\
\text { Family } \\
\text { household } \\
\text { income } \\
\text { (per } \\
\text { month) } \\
\text { (RM) }\end{array}$} & $\begin{array}{l}\text { RM4,359 } \\
\text { below }\end{array}$ & 316 & 68.7 & 21.36 & 5.516 & 1.385 & 0.251 \\
\hline & $\mathrm{RM} 4,360$ & 96 & 20.9 & 22.42 & 5.471 & & \\
\hline & RM9,619 & 48 & 10.4 & 21.44 & 5.454 & & \\
\hline & $\begin{array}{l}\text { RM9,620 } \\
\text { above }\end{array}$ & & & & & & \\
\hline Location & \multirow{3}{*}{$\begin{array}{l}\text { Residential } \\
\text { College } \\
\text { Others }\end{array}$} & 145 & 31.0 & 21.50 & 5.512 & 0.250 & 0.803 \\
\hline when & & & & & & & \\
\hline $\begin{array}{l}\text { attending } \\
\text { online }\end{array}$ & & & & & & & \\
\hline
\end{tabular}

T\&L

$\begin{array}{lllll}\text { Home } & 323 & 69.0 & 21.64 & 5.499\end{array}$

$$
* \mathrm{P}<0.05
$$$$
* * \mathrm{P}<0.01
$$

Table 3. The Relationship Between Respondents' Background and Friends' Support

\begin{tabular}{llcccccc}
\hline Item & & $\mathbf{n}$ & $\boldsymbol{\%}$ & Mean & $\begin{array}{c}\text { Standard } \\
\text { Deviation }\end{array}$ & t/F & P Value \\
\hline Age & 20 and below & 121 & 25.9 & 20.30 & 5.154 & 1.829 & 0.162 \\
& $21-22$ & 292 & 62.3 & 21.25 & 5.097 & & \\
& 23 and above & 55 & 11.8 & 21.62 & 5.526 & & \\
\hline
\end{tabular}




\begin{tabular}{|c|c|c|c|c|c|c|c|}
\hline \multirow[t]{2}{*}{ Sex } & Male & 107 & 22.9 & 20.64 & 5.107 & 0.932 & 0.352 \\
\hline & Female & 361 & 77.1 & 21.17 & 5.192 & & \\
\hline \multirow[t]{5}{*}{ Race } & Malay & 328 & 70.1 & 20.83 & 5.342 & 0.850 & 0.467 \\
\hline & Chinese & 74 & 15.8 & 21.84 & 4.092 & & \\
\hline & Indian and others & 29 & 6.2 & 21.52 & 5.717 & & \\
\hline & Bumiputera & 37 & 7.9 & 21.00 & 5.159 & & \\
\hline & Sabah/Sarawak & & & & & & \\
\hline \multirow{3}{*}{$\begin{array}{l}\text { Level } \\
\text { Study }\end{array}$} & Diploma & 33 & 7.1 & 20.06 & 6.062 & 1.134 & 0.257 \\
\hline & others & 435 & 92.9 & 21.12 & 5.099 & & \\
\hline & Bachelor & & & & & & \\
\hline \multirow{3}{*}{$\begin{array}{l}\text { Year } \\
\text { Study }\end{array}$} & Year 1 & 209 & 44.7 & 21.17 & 4.904 & 0.726 & 0.485 \\
\hline & Year 2 & 184 & 39.3 & 20.72 & 5.197 & & \\
\hline & Year 3 and above & 75 & 16.0 & 21.51 & 5.823 & & \\
\hline \multirow{7}{*}{$\begin{array}{l}\text { Estimated } \\
\text { Family } \\
\text { household } \\
\text { income } \\
\text { (per } \\
\text { month) } \\
\text { (RM) }\end{array}$} & RM4,359 & 316 & 68.7 & 20.89 & 5.334 & 0.651 & 0.522 \\
\hline & below & 96 & 20.9 & 21.56 & 5.107 & & \\
\hline & $\mathrm{RM} 4,360$ & 48 & 10.4 & 21.23 & 4.401 & & \\
\hline & RM9,619 & & & & & & \\
\hline & RM9,620 & & & & & & \\
\hline & above & & & & & & \\
\hline & & & & & & & \\
\hline \multirow{3}{*}{$\begin{array}{l}\text { Location } \\
\text { when } \\
\text { attending } \\
\text { online }\end{array}$} & Residential & 145 & 31.0 & 20.86 & 5.377 & 0.512 & 0.466 \\
\hline & College or Others & & & & & & \\
\hline & & & & & & & \\
\hline
\end{tabular}

$\mathrm{T} \& \mathrm{~L}$

Home

$\begin{array}{llll}323 & 69.0 & 21.13 & 5.084\end{array}$

$* \mathrm{P}<0.05$

$* * \mathrm{P}<0.01$ 
Table 4. The Relationship Between Respondents' Background and Support from Other People Close to them

\begin{tabular}{|c|c|c|c|c|c|c|c|}
\hline Item & & n & $\%$ & Min & $\begin{array}{l}\text { Standard } \\
\text { Deviation }\end{array}$ & $t / F$ & P Value \\
\hline \multirow[t]{3}{*}{ Age } & 20 and below & 121 & 25.9 & 18.54 & 6.707 & 0.555 & 0.575 \\
\hline & $21-22$ & 292 & 62.3 & 18.73 & 6.853 & & \\
\hline & 23 and above & 55 & 11.8 & 19.67 & 6.918 & & \\
\hline \multirow[t]{2}{*}{ Sex } & \multirow{2}{*}{$\begin{array}{l}\text { Male } \\
\text { Female } \\
\end{array}$} & 107 & 22.9 & 18.02 & 6.791 & 1.335 & 0.183 \\
\hline & & 361 & 77.1 & 19.02 & 6.817 & & \\
\hline \multirow[t]{4}{*}{ Race } & Malay & 328 & 70.1 & 18.39 & 6.931 & 1.729 & 0.160 \\
\hline & Chinese & 74 & 15.8 & 20.14 & 5.491 & & \\
\hline & Indian and others & 29 & 6.2 & 18.41 & 7.730 & & \\
\hline & $\begin{array}{l}\text { Bumiputera } \\
\text { Sabah/ Sarawak }\end{array}$ & 37 & 7.9 & 19.95 & 7.226 & & \\
\hline \multirow{2}{*}{$\begin{array}{l}\text { Level } \\
\text { Study }\end{array}$} & \multirow{2}{*}{$\begin{array}{l}\text { Diploma } \\
\text { others } \\
\text { Bachelor }\end{array}$} & 33 & 7.1 & 17.00 & 8.400 & 1.568 & 0.118 \\
\hline & & 435 & 92.9 & 18.93 & 8.674 & & \\
\hline \multirow{3}{*}{$\begin{array}{l}\text { Year } \\
\text { Study }\end{array}$} & Year 1 & 209 & 44.7 & 19.36 & 6.233 & 1.373 & 0.254 \\
\hline & Year 2 & 184 & 39.3 & 18.26 & 6.946 & & \\
\hline & Year 3 and above & 75 & 16.0 & 18.51 & 7.940 & & \\
\hline \multirow{4}{*}{$\begin{array}{l}\text { Estimated } \\
\text { Family } \\
\text { household } \\
\text { income } \\
\text { (per } \\
\text { month) } \\
\text { (RM) }\end{array}$} & $\begin{array}{l}\text { RM4,359 and } \\
\text { below }\end{array}$ & 316 & 68.7 & 18.38 & 6.886 & 2.969 & 0.052 \\
\hline & $\mathrm{RM} 4,360$ & 96 & 20.9 & 20.30 & 6.483 & & \\
\hline & RM9,619 & 48 & 10.4 & 18.67 & 6.783 & & \\
\hline & $\begin{array}{l}\text { RM9,620 and } \\
\text { above }\end{array}$ & & & & & & \\
\hline $\begin{array}{l}\text { Location } \\
\text { when } \\
\text { attending } \\
\text { online }\end{array}$ & $\begin{array}{l}\text { Residential } \\
\text { College or Others }\end{array}$ & 145 & 31.0 & 19.02 & 6.644 & 0.489 & 0.625 \\
\hline
\end{tabular}

T\&L

$$
\text { Home }
$$$$
323 \quad 69.0 \quad 18.69
$$

$* \mathrm{P}<0.05$

$* * \mathrm{P}<0.01$

3.2.1 The Relationship between Supports Provided by Family, Friends and Other People Close to Them

Figure 5 below shows the relationships between the three sources of social support. The results of the correlation analysis found that there was a significant association between family support with peer support $(r=0.647, \mathrm{p}<0.01)$, which supports the findings of previous 
researchers (Çevik \& Yildiz, 2017; Yang et al., 2021). This finding suggests that these two sources of support have a strong relationship with each other. This finding indicates that in this COVID-19 pandemic, students get more support from family and friends, specifically material, mental and emotional support. Family support can reduce feelings of loneliness and have an exclusive role in reducing depressive symptoms (Mariani et al., 2020). In addition, support from family and friends also helps overcome anxiety (Bourion-Bédès et al., 2021) and improve quality of life (Alsubaie et al., 2019).

Subsequent findings have also shown a significant relationship between family support and the support from other people close to them $(r=0.411, \mathrm{p}<0.01)$. Hence, similar to family support, support from other people close to them has a positive effect on students. In this case, students receive support from close friends or university staff like lecturers, principals, fellows, and residential college staff while living on campus. These findings support a previous study by Permatasari et al. (2021), which stated that family and other close parties positively contribute to students' well-being during online learning and help build academic resilience during online learning. Furthermore, the analysis also showed that there is a significant relationship between peer support and the support of other close individuals $(\mathrm{r}=$ $0.565, \mathrm{p}<0.01$ ), in line with the findings by Khatiwada et al. (2021). This finding further indicates a strong relationship between these two sources of social support. According to Salimi and Bozorgpour (2012), support from others also has a role in reducing loneliness experienced by students, similar to support from family and friends.

Table 5. Relationship between supports provided by family, friends, and other people close to them

\begin{tabular}{|c|c|c|c|c|c|c|c|}
\hline & Item & Mean & $\begin{array}{l}\text { Standard } \\
\text { deviation }\end{array}$ & & 1 & 2 & 3 \\
\hline 1 & Family Support & 21.60 & 5.497 & $\begin{array}{c}\text { Pearson } \\
\text { Correlation } \\
\text { Sig }(2 \text {-tailed }) \\
\mathrm{N}\end{array}$ & 1 & & \\
\hline 2 & Friends' Support & 21.04 & 5.172 & $\begin{array}{c}\text { Pearson } \\
\text { Correlation } \\
\text { Sig (2-tailed }) \\
\mathrm{N}\end{array}$ & $\begin{array}{c}0.647 * * \\
0.000 \\
468\end{array}$ & 1 & \\
\hline 3 & $\begin{array}{l}\text { Support from } \\
\text { other people }\end{array}$ & 18.79 & 6.817 & $\begin{array}{c}\text { Pearson } \\
\text { Correlation } \\
\text { Sig }(2 \text {-tailed }) \\
\mathrm{N}\end{array}$ & $\begin{array}{c}0.411 * * \\
0.000 \\
468\end{array}$ & $\begin{array}{c}0.565 * * \\
0.000 \\
468\end{array}$ & 1 \\
\hline
\end{tabular}

$* \mathrm{P}<0.05$

$* * \mathrm{P}<0.01$

\section{Conclusion}

Social support plays an important role in students' mental and emotional stability, especially 
during the challenging COVID-19 pandemic. Although the survey findings show that the students receive adequate social support throughout the pandemic, social support should always be examined from time to time. Furthermore, on-going social support must be fully utilized to avoid any issues that could negatively impact students and their academic performance.

\section{Acknowledgments}

There is no research grant funded in this study. There are also no conflicts of interest in this study. The main author was involved in developing the questionnaire form, data collection, data analysis, and subtitle writing, while the other authors were involved in the subtitle writing. All authors are involved in the review and improve the draft writing and consent to be submitted for publication. The research team would like to express many appreciation and gratitude to all who have been involved in this study whether directly or indirectly.

\section{References}

Alia, A. A., Huzili, H., \& Aida, S. I. (2016). Sokongan Sosial dan Program Pemulihan yang Diperlukan oleh Penagih Dadah. Seminar Psikologi Kebangsaan-iii 2016, Kota Kinabalu, Sabah, 26 \& 27 Mei 2016.

Alsubaie, M. M., Stain, H. J., Webster, L. A. D., \& Wadman, R. (2019). The role of sources of social support on depression and quality of life for university students. International Journal of Adolescence Youth, 24(4), 484-496.

Bourion-Bédès, S., Tarquinio, C., Batt, M., Tarquinio, P., Lebreuilly, R., Sorsana, C., Baumann, C. (2021). Psychological impact of the COVID-19 outbreak on students in a French region severely affected by the disease: Results of the PIMS-CoV 19 study. Psychiatry research, 295, 113559.

Çevik, G. B., \& Yildiz, M. A. (2017). The Roles of Perceived Social Support, Coping, and Loneliness in Predicting Internet Addiction in Adolescents. Journal of Education Practice, $8(12), 64-73$.

Dewaele, J.-M. (2018). Online questionnaires. In The Palgrave handbook of applied linguistics research methodology (pp. 269-286). Springer.

El-Zoghby, S. M., Soltan, E. M., \& Salama, H. M. (2020). Impact of the COVID-19 pandemic on mental health and social support among adult Egyptians. Journal of community health, 45, 689-695.

Eskin, M. (2003). Self-reported assertiveness in Swedish and Turkish adolescents: A cross-cultural comparison. Scandinavian Journal of Psychology, 44(1), 7-12.

Grey, I., Arora, T., Thomas, J., Saneh, A., Tohme, P., \& Abi-Habib, R. (2020). The role of perceived social support on depression and sleep during the COVID-19 pandemic. Psychiatry research, 293, 113452.

Guan, N. C., Nurasikin, M., Loh, H., HA, A. Y., \& Zainal, N. (2012). Factorial validation of 
the Malay version of multidimensional scale of perceived social support among a group of psychiatric patients. Malaysian Journal of Psychiatry, 21(2).

Guo, K., Zhang, X., Bai, S., Minhat, H. S., Nazan, A. I. N. M., Feng, J., Feng, J. (2021). Assessing social support impact on depression, anxiety, and stress among undergraduate students in Shaanxi province during the COVID-19 pandemic of China. PloS one, 16(7), e0253891.

Harapan, H., Itoh, N., Yufika, A., Winardi, W., Keam, S., Te, H., Mudatsir, M. (2020). Coronavirus disease 2019 (COVID-19): A literature review. Journal of infection public health, 13(5), 667-673.

Khatiwada, J., Muzembo, B. A., Wada, K., \& Ikeda, S. (2021). The effect of perceived social support on psychological distress and life satisfaction among Nepalese migrants in Japan. PloS one, 16(2), e0246271.

Li, Y., Zhao, J., Ma, Z., McReynolds, L. S., Lin, D., Chen, Z., Zhang, J. (2021). Mental health among college students during the COVID-19 pandemic in China: A 2-wave longitudinal survey. Journal of affective disorders, 281, 597-604.

Mariani, R., Renzi, A., Di Trani, M., Trabucchi, G., Danskin, K., \& Tambelli, R. (2020). The impact of coping strategies and perceived family support on depressive and anxious symptomatology during the coronavirus pandemic (COVID-19) lockdown. Frontiers in Psychiatry, 11, 1195.

Ng, C., Siddiq, A. A., Aida, S., Zainal, N., \& Koh, O. (2010). Validation of the Malay version of the Multidimensional Scale of Perceived Social Support (MSPSS-M) among a group of medical students in Faculty of Medicine, University Malaya. Asian J. Psychiatric, 3(1), 3-6.

OECD Tackling Coronavirus (Covid-19): Contributing to a Global Effort. The territorial impact of COVID-19: Managing the crisis across levels of government. (as of 10 November 2020),

https://www.oecd.org/coronavirus/policy-responses/the-territorial-impact-of-covid-19-managi ng-the-crisis-across-levels-of-government-d3e314e1/

Paykani, T., Zimet, G. D., Esmaeili, R., Khajedaluee, A. R., \& Khajedaluee, M. (2020). Perceived social support and compliance with stay-at-home orders during the COVID-19 outbreak: evidence from Iran. BMC Public Health, 20(1), 1-9.

Permatasari, N., Ashari, F. R., \& Ismail, N. (2021). Contribution of Perceived Social Support (Peer, Family, and Teacher) to Academic Resilience during COVID-19. Golden Ratio of Social Science and Educational, 1(1), 01-12.

Şahin, D. S., Özer, Ö., \& Yanardağ, M. Z. (2019). Perceived social support, quality of life, and satisfaction with life in elderly people. Educational Gerontology, 45(1), 69-77.

Salimi, A., \& Bozorgpour, F. (2012). Perceived social support and social-emotional loneliness. Procedia-Social Behavioral Sciences, 69, 2009-2013. 


\section{Macrothink}

International Journal of Human Resource Studies

ISSN 2162-3058 2021, Vol. 11, No. 4S

Son, C., Hegde, S., Smith, A., Wang, X., \& Sasangohar, F. (2020). Effects of COVID-19 on college students' mental health in the United States: Interview survey study. Journal of medical internet research, 22(9), e21279.

Sundarasen, S., Chinna, K., Kamaludin, K., Nurunnabi, M., Baloch, G. M., Khoshaim, H. B., Sukayt, A. (2020). Psychological impact of COVID-19 and lockdown among university students in Malaysia: implications and policy recommendations. International journal of environmental research public health, 17(17), 6206.

Talwar, P., \& Rahman, M. F. A. (2013). Perceived social support among University students in Malaysia: A reliability study. Malaysian Journal of Psychiatry, 22(1).

T.B. Liu, X.Y. Chen, G.D. Miao, et al (2003). Recommendations on diagnostic criteria and prevention of SARS-related mental disorders. J Clin Psychol, 13, 188-191.

Yang, C., Xia, M., \& Zhou, Y. (2021). How do specific social supports (family, friend, and specialist) reduce stress in patients with substance use disorders (SUD): A multiple mediation analysis. Frontiers in Psychiatry, 12, 1024.

Zimet, G. D., Dahlem, N. W., Zimet, S. G., \& Farley, G. K. (1988). The multidimensional scale of perceived social support. Journal of personality assessment, 52(1), 30-41.

\section{Appendix}

Table 1. Descriptive Analysis of Respondents' Backgrounds

\begin{tabular}{|c|c|c|c|c|}
\hline Item & n & $\%$ & Mean & $\begin{array}{l}\text { Standard } \\
\text { Deviation }\end{array}$ \\
\hline Age & 468 & 100 & 21.24 & 1.359 \\
\hline \multicolumn{5}{|l|}{$\operatorname{Sex}$} \\
\hline Male & 107 & 22.9 & & \\
\hline Female & 361 & 77.1 & & \\
\hline \multicolumn{5}{|l|}{ Race } \\
\hline Malay & 328 & 70.1 & & \\
\hline Chinese & 74 & 15.8 & & \\
\hline Indian & 24 & 5.1 & & \\
\hline Bumiputera Sabah/Sarawak & 37 & 7.9 & & \\
\hline Others & 5 & 1.1 & & \\
\hline \multicolumn{5}{|l|}{ Residential College } \\
\hline Kolej Tun Dr. Ismail & 188 & 40.2 & & \\
\hline Kolej Canselor & 3 & 0.6 & & \\
\hline Kolej Sultan Alaeddin & 8 & 1.7 & & \\
\hline \multicolumn{5}{|l|}{ Suleiman Shah } \\
\hline Kolej Pendeta Za'ba & 88 & 18.8 & & \\
\hline Kolej Sepuluh & 55 & 11.8 & & \\
\hline
\end{tabular}


Kolej Dua Belas

Kolej Empat Belas

Kolej Tujuh Belas

Kolej Sri Rajang

Level of study

Diploma

Bachelor

Master

$\mathrm{PhD}$

Year of Study

Year 1
Year 2
Year 3
Year 4
Year 5
Year 5 and more

Estimated family household monthly income (Per month) (RM)

Location when attending online T\&L

Home

Residential College

Residential College and

Faculty/Institute
24

37

1

64

$31 \quad 6.6$

435

92.9

$1 \quad 0.2$

$1 \quad 0.2$

$209 \quad 44.7$

$184 \quad 39.3$

$64 \quad 13.7$

$\begin{array}{ll}8 & 1.7\end{array}$

$2 \quad 0.4$

$1 \quad 0.2$

$\begin{array}{llll}460 & 98.3 & \mathrm{RM} 4,145.59 & 4061.947\end{array}$

External Organization/Agency $\quad 1 \quad 2.0$


Table 2. The Relationship Between Respondents' Background and Family Support

\begin{tabular}{|c|c|c|c|c|c|c|c|}
\hline Item & & $\mathbf{n}$ & $\%$ & Mean & $\begin{array}{l}\text { Standard } \\
\text { Deviation }\end{array}$ & $t / F$ & P value \\
\hline \multirow[t]{3}{*}{ Age } & 20 and below & 121 & 25.9 & 20.97 & 5.679 & 1.250 & 0.287 \\
\hline & $21-22$ & 292 & 62.3 & 21.74 & 5.496 & & \\
\hline & 23 and above & 55 & 11.8 & 22.22 & 5.050 & & \\
\hline \multirow[t]{2}{*}{ Sex } & Male & 107 & 22.9 & 21.50 & 5.438 & 0.220 & 0.826 \\
\hline & Female & 361 & 77.1 & 21.63 & 5.522 & & \\
\hline \multirow[t]{4}{*}{ Race } & Malay & 328 & 70.1 & 21.23 & 5.650 & 1.973 & 0.117 \\
\hline & Chinese & 74 & 15.8 & 22.31 & 4.388 & & \\
\hline & Indian and others & 29 & 6.2 & 23.34 & 5.143 & & \\
\hline & $\begin{array}{l}\text { Bumiputera } \\
\text { Sabah/ Sarawak }\end{array}$ & 37 & 7.9 & 22.05 & 6.123 & & \\
\hline \multirow{3}{*}{$\begin{array}{ll}\text { Level of } \\
\text { Study }\end{array}$} & \multirow{3}{*}{$\begin{array}{l}\text { Diploma } \\
\text { others } \\
\text { Bachelor }\end{array}$} & 33 & 7.1 & 20.03 & 6.706 & 1.703 & 0.089 \\
\hline & & 435 & 92.9 & 21.72 & 5.385 & & \\
\hline & & & & & & & \\
\hline \multirow{3}{*}{$\begin{array}{l}\text { Year } \\
\text { Study }\end{array}$} & Year 1 & 209 & 44.7 & 21.72 & 5.338 & 0.097 & 0.908 \\
\hline & Year 2 & 184 & 39.3 & 21.49 & 5.398 & & \\
\hline & Year 3 and above & 75 & 16.0 & 21.52 & 6.202 & & \\
\hline \multirow{6}{*}{$\begin{array}{l}\text { Estimated } \\
\text { Family } \\
\text { household } \\
\text { income } \\
\text { (per } \\
\text { month) } \\
\text { (RM) }\end{array}$} & RM4,359 & 316 & 68.7 & 21.36 & 5.516 & 1.385 & 0.251 \\
\hline & below & & & & & & \\
\hline & RM4,360 & 96 & 20.9 & 22.42 & 5.471 & & \\
\hline & RM9,619 & 48 & 10.4 & 21.44 & 5.454 & & \\
\hline & RM9,620 & & & & & & \\
\hline & above & & & & & & \\
\hline \multirow{4}{*}{$\begin{array}{l}\text { Location } \\
\text { when } \\
\text { attending } \\
\text { online } \\
\text { T\&L }\end{array}$} & Residential & 145 & 31.0 & 21.50 & 5.512 & 0.250 & 0.803 \\
\hline & College & & & & & & \\
\hline & Others & & & & & & \\
\hline & Home & 323 & 69.0 & 21.64 & 5.499 & & \\
\hline
\end{tabular}


Table 3. The Relationship Between Respondents' Background and Friends' Support

\begin{tabular}{|c|c|c|c|c|c|c|c|}
\hline Item & & $\mathbf{n}$ & $\%$ & Mean & $\begin{array}{l}\text { Standard } \\
\text { Deviation }\end{array}$ & $t / \mathbf{F}$ & P Value \\
\hline \multirow[t]{3}{*}{ Age } & 20 and below & 121 & 25.9 & 20.30 & 5.154 & 1.829 & 0.162 \\
\hline & $21-22$ & 292 & 62.3 & 21.25 & 5.097 & & \\
\hline & 23 and above & 55 & 11.8 & 21.62 & 5.526 & & \\
\hline \multirow[t]{2}{*}{ Sex } & Male & 107 & 22.9 & 20.64 & 5.107 & 0.932 & 0.352 \\
\hline & Female & 361 & 77.1 & 21.17 & 5.192 & & \\
\hline \multirow[t]{5}{*}{ Race } & Malay & 328 & 70.1 & 20.83 & 5.342 & 0.850 & 0.467 \\
\hline & Chinese & 74 & 15.8 & 21.84 & 4.092 & & \\
\hline & Indian and others & 29 & 6.2 & 21.52 & 5.717 & & \\
\hline & Bumiputera & 37 & 7.9 & 21.00 & 5.159 & & \\
\hline & Sabah/ Sarawak & & & & & & \\
\hline \multirow{3}{*}{$\begin{array}{l}\text { Level } \\
\text { Study }\end{array}$} & Diploma and & 33 & 7.1 & 20.06 & 6.062 & 1.134 & 0.257 \\
\hline & others & 435 & 92.9 & 21.12 & 5.099 & & \\
\hline & Bachelor & & & & & & \\
\hline \multirow{3}{*}{$\begin{array}{l}\text { Year } \\
\text { Study }\end{array}$} & Year 1 & 209 & 44.7 & 21.17 & 4.904 & 0.726 & 0.485 \\
\hline & Year 2 & 184 & 39.3 & 20.72 & 5.197 & & \\
\hline & Year 3 and above & 75 & 16.0 & 21.51 & 5.823 & & \\
\hline \multirow{6}{*}{$\begin{array}{l}\text { Estimated } \\
\text { Family } \\
\text { household } \\
\text { income } \\
\text { (per } \\
\text { month) } \\
\text { (RM) }\end{array}$} & RM4,359 and & 316 & 68.7 & 20.89 & 5.334 & 0.651 & 0.522 \\
\hline & below & 96 & 20.9 & 21.56 & 5.107 & & \\
\hline & RM4,360 & 48 & 10.4 & 21.23 & 4.401 & & \\
\hline & RM9,619 & & & & & & \\
\hline & RM9,620 and & & & & & & \\
\hline & above & & & & & & \\
\hline \multirow{3}{*}{$\begin{array}{l}\text { Location } \\
\text { when } \\
\text { attending } \\
\text { online } \\
\text { T\&L }\end{array}$} & Residential & 145 & 31.0 & 20.86 & 5.377 & 0.512 & 0.466 \\
\hline & College or Others & & & & & & \\
\hline & Home & 323 & 69.0 & 21.13 & 5.084 & & \\
\hline
\end{tabular}


Table 4. The Relationship Between Respondents' Background and Support from Other People Close to them

\begin{tabular}{|c|c|c|c|c|c|c|c|}
\hline Item & & $\mathbf{n}$ & $\%$ & Min & $\begin{array}{l}\text { Standard } \\
\text { Deviation }\end{array}$ & $t / F$ & P Value \\
\hline \multirow[t]{3}{*}{ Age } & 20 and below & 121 & 25.9 & 18.54 & 6.707 & 0.555 & 0.575 \\
\hline & $21-22$ & 292 & 62.3 & 18.73 & 6.853 & & \\
\hline & 23 and above & 55 & 11.8 & 19.67 & 6.918 & & \\
\hline \multirow[t]{2}{*}{ Sex } & Male & 107 & 22.9 & 18.02 & 6.791 & 1.335 & 0.183 \\
\hline & Female & 361 & 77.1 & 19.02 & 6.817 & & \\
\hline \multirow[t]{5}{*}{ Race } & Malay & 328 & 70.1 & 18.39 & 6.931 & 1.729 & 0.160 \\
\hline & Chinese & 74 & 15.8 & 20.14 & 5.491 & & \\
\hline & Indian and others & 29 & 6.2 & 18.41 & 7.730 & & \\
\hline & \multirow{2}{*}{$\begin{array}{l}\text { Bumiputera } \\
\text { Sabah/ Sarawak }\end{array}$} & 37 & 7.9 & 19.95 & 7.226 & & \\
\hline & & & & & & & \\
\hline \multirow{3}{*}{$\begin{array}{l}\text { Level } \\
\text { Study }\end{array}$} & \multirow{3}{*}{$\begin{array}{l}\text { Diploma } \\
\text { others } \\
\text { Bachelor }\end{array}$} & 33 & 7.1 & 17.00 & 8.400 & 1.568 & 0.118 \\
\hline & & 435 & 92.9 & 18.93 & 8.674 & & \\
\hline & & & & & & & \\
\hline \multirow{3}{*}{$\begin{array}{l}\text { Year } \\
\text { Study }\end{array}$} & Year 1 & 209 & 44.7 & 19.36 & 6.233 & 1.373 & 0.254 \\
\hline & Year 2 & 184 & 39.3 & 18.26 & 6.946 & & \\
\hline & Year 3 and above & 75 & 16.0 & 18.51 & 7.940 & & \\
\hline \multirow{6}{*}{$\begin{array}{l}\text { Estimated } \\
\text { Family } \\
\text { household } \\
\text { income } \\
\text { (per } \\
\text { month) } \\
\text { (RM) }\end{array}$} & $\mathrm{RM} 4,359$ & 316 & 68.7 & 18.38 & 6.886 & 2.969 & 0.052 \\
\hline & below & & & & & & \\
\hline & $\mathrm{RM} 4,360$ & 96 & 20.9 & 20.30 & 6.483 & & \\
\hline & RM9,619 & 48 & 10.4 & 18.67 & 6.783 & & \\
\hline & RM9,620 & & & & & & \\
\hline & above & & & & & & \\
\hline Location & \multirow{2}{*}{$\begin{array}{l}\text { Residential } \\
\text { College or Others }\end{array}$} & 145 & 31.0 & 19.02 & 6.644 & 0.489 & 0.625 \\
\hline $\begin{array}{l}\text { when } \\
\text { attending } \\
\text { online }\end{array}$ & & & & & & & \\
\hline
\end{tabular}

$\mathrm{T} \& \mathrm{~L}$

Home

$323 \quad 69.0 \quad 18.69$

6.901

$* \mathrm{P}<0.05$

$* * \mathrm{P}<0.01$ 
Table 5. Relationship between supports provided by family, friends, and other people close to them.

\begin{tabular}{|c|c|c|c|c|c|c|c|}
\hline & Item & Mean & $\begin{array}{l}\text { Standard } \\
\text { deviation }\end{array}$ & & 1 & 2 & 3 \\
\hline 1 & Family Support & 21.60 & 5.497 & $\begin{array}{c}\text { Pearson } \\
\text { Correlation } \\
\text { Sig } \\
\text { (2-tailed) } \\
\mathrm{N}\end{array}$ & 1 & & \\
\hline 2 & Friends' Support & 21.04 & 5.172 & $\begin{array}{c}\text { Pearson } \\
\text { Correlation } \\
\text { Sig } \\
\text { (2-tailed) } \\
\mathrm{N}\end{array}$ & $\begin{array}{c}0.647 * * \\
0.000 \\
468\end{array}$ & 1 & \\
\hline 3 & $\begin{array}{l}\text { Support from other } \\
\text { people }\end{array}$ & 18.79 & 6.817 & $\begin{array}{c}\text { Pearson } \\
\text { Correlation } \\
\text { Sig } \\
\text { (2-tailed) } \\
\mathrm{N}\end{array}$ & $\begin{array}{c}0.411 * * \\
0.000 \\
468\end{array}$ & $\begin{array}{c}0.565 * * \\
0.000 \\
468\end{array}$ & 1 \\
\hline
\end{tabular}

$* \mathrm{P}<0.05$

$* * \mathrm{P}<0.01$

\section{Copyright Disclaimer}

Copyright for this article is retained by the author(s), with first publication rights granted to the journal.

This is an open-access article distributed under the terms and conditions of the Creative Commons Attribution license (http://creativecommons.org/licenses/by/4.0/). 